\title{
Rat hepatic microsomal glucose-6-phosphatase protein levels are increased in streptozotocin-induced diabetes
}

\author{
A. Burchell and D. I. Cain \\ Department of Biochemistry, Medical Sciences Institute, University of Dundee, Scotland, UK
}

\begin{abstract}
Summary. Hepatic microsomal glucose-6-phosphatase activity levels and the hepatic output of glucose are increased in diabetes. We have used protein chemistry and immunological techniques to determine the mechanism by which the activity levels of the glucose-6-phosphatase system are increased in streptozotocin-induced diabetic rats. In the streptozotocin-induced diabetic rats, the activity of the glucose-6-phosphatase enzyme increased four-fold without appreciably altering the transport capacity of the glucose-6-phosphatase system. The solubilized diabetic rat liver glucose-6-phosphatase enzyme appeared to be very similar to the solubilized enzyme from control rat liver microsomes. They exhibit the same $\mathrm{Km}$, are labile at $30^{\circ} \mathrm{C}$, are stabilized by sodium fluoride and they mi-
\end{abstract}

grate to the same position during density gradient centrifugation. Immunological studies demonstrated that a greater amount of hepatic microsomal glucose-6-phosphatase enzyme protein is present in diabetic rats than in control rats. Thus, we have determined for the first time that increased levels of the glucose-6-phosphatase protein are present in streptozotocin-induced diabetes. The significance of this finding in relation to the regulation of the hepatic microsomal glucose6-phosphatase system is discussed.

Key words. Glucose-6-phosphatase, glucose-6-phosphate, diabetes, antibodies, blood glucose levels.
Hepatic microsomal glucose-6-phosphatase (EC 3.1.3.9) is, potentially, the most important enzyme involved in homeostatic regulation of blood glucose concentrations [1,2]. Substantial kinetic [3-5] and genetic [6-8] evidence indicates that glucose-6-phosphatase hydrolysis in the glucogenic tissues is catalysed by a multicomponent system. It has been proposed [3] that the active site of glucose-6-phosphatase in intact microsomes (microsomal fractions) is situated at the lumenal surface of the membrane and that a specific translocase $\left(\mathrm{T}_{1}\right)$ mediates entry of glucose-6-phosphate. Phosphate $\left(\mathrm{P}_{\mathrm{i}}\right)$, released at the lumenal surface, is believed to equilibrate via a second translocase, $\mathrm{T}_{2}[5]$. The mechanism of glucose permeation across the membrane has not yet been elucidated, but the glucose transporter has been designated $\mathrm{T}_{3}[5]$.

The rate of hydrolysis of glucose-6-phosphate by the hepatic microsomal glucose-6-phosphatase system and the hepatic output of glucose were increased in all the diabetic conditions studied $[9,10]$. Glucose-6-phosphatase activity and hepatic glucose production are decreased by insulin in both normal and diabetic animals $[10,11]$.
In chemically-induced diabetes in rats kinetic evidence indicates that glucose-6-phosphatase enzyme activity is increased $3 \sim 4$ fold without appreciably altering the activity of the translocases [5,9].

An understanding of the mechanisms involved in the control of glucose-6-phosphatase activity in the diabetic state is essential for our understanding of the increased hepatic output of glucose in diabetes. However, nothing is known about the mechanism by which glucose-6-phosphatase activity is elevated in diabetes.

Therefore, the aim of this study was to determine the mechanism by which the levels of glucose-6-phosphatase enzyme activity are elevated in diabetes.

\section{Materials and methods}

\section{Materials}

Glucose-6-phosphate, mannose-6-phosphate, cholic acid and deoxycholic acid were purchased from Sigma Chemical Co., Poole, Dorset, U.K. Lubrol 12A-9 (a condensate of dodceyl alcohol with approximately $9.5 \mathrm{~mol}$ of ethylene oxide) was obtained from ICI Organics Division, Manchester, U.K. Freund's complete adjuvant was purchased from Grand Island Biological Company, Grand Island, USA. All other chemicals were analytical reagent grade. 
Table 1. Glucose-6-phosphatase activity in control and diabetic rat liver microsomes

\begin{tabular}{lll}
\hline & Control rats & Diabetic rats \\
\hline $\begin{array}{l}\text { Specific activity of glucose- } \\
\text { 6-phosphatase in intact micro- }\end{array}$ & $0.19(0.18-0.21)$ & $0.28(0.25-0.30)$ \\
$\begin{array}{l}\text { somes } \\
\begin{array}{l}\text { Specific activity of glucose- } \\
\text { 6-phosphatase in disrupted mi- } \\
\text { crosomes }\end{array}\end{array}$ & $0.22(0.20-0.26)$ & $0.91(0.76-1.03)$ \\
Latency & $12 \%(9-16)$ & $65 \%(56-69)$ \\
\hline
\end{tabular}

Data are the mean from at least four separate preparations. Numbers in parenthesis are the range of values obtained. Specific activity is expressed as $\mu \mathrm{mol} \cdot \mathrm{mg}^{-1} \cdot \mathrm{min}^{-1}$ protein.

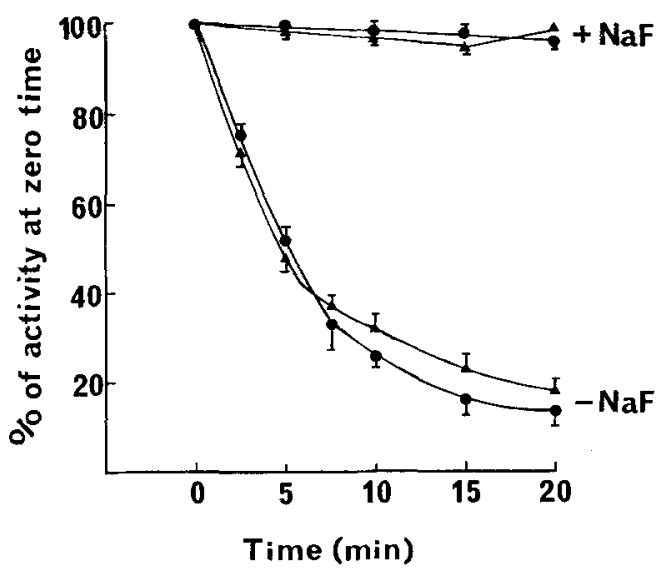

Fig. 1. Stability of glucose-6-phosphatase activity. Diabetic $\mathbf{A - \Lambda}$ and control cholate solubilized rat liver microsomes were incubated at a protein concentration of $1.5 \mathrm{mg} / \mathrm{ml}$ at $30^{\circ} \mathrm{C}$ in the presence or absence of $50 \mathrm{mmol}$ sodium fluoride. Results shown are the mean and range of activities obtained using three different microsomal preparations

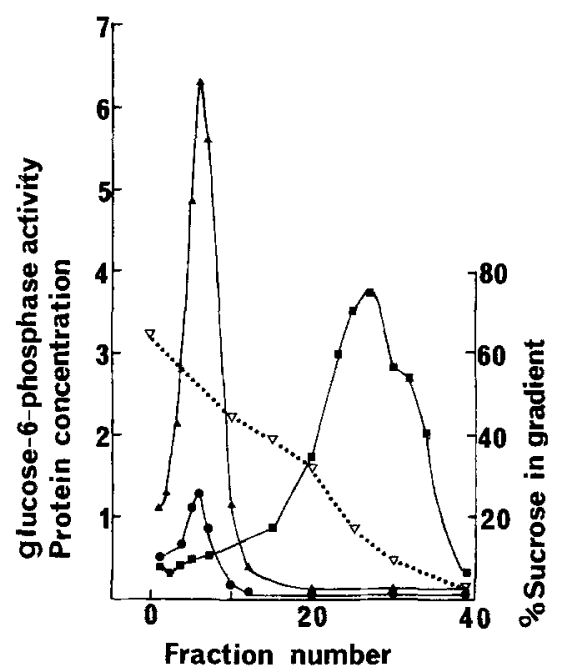

Fig. 2. Sucrose-gradient density centrifugation of control and diabetic rat liver microsomes. $\nabla \cdots \cdots \nabla \%$ sucrose in gradient fractions, $\Lambda$ - glucose-6-phosphatase activity from diabetic rat liver microsomes expressed in $\mu \mathrm{mol} \cdot \mathrm{ml}^{-1} \cdot \mathrm{min}^{-1}$, glucose 6-phosphatase activity from control rat liver microsomes expressed in $\mu \mathrm{mol} \cdot \mathrm{ml}^{-1} \cdot \mathrm{min}^{-1}$, $\mathbf{E}$ protein concentration $(\mathrm{mg} / \mathrm{ml}$ ) from control rat liver microsomes. A similar protein concentration profile was obtained from diabetic rat liver microsomes (data not shown)

\section{Animals}

To induce experimental diabetes, male Wistar rats (approximately $200 \mathrm{~g}$ ) were given a single tail vein injection of streptozotocin $(100 \mathrm{mg} / \mathrm{kg}$ body weight) in citrate-buffered $(\mathrm{pH} 4.5)$ isotonic saline [5]. Only fed animals with blood glucose concentrations over $18 \mathrm{mmol} / \mathrm{I}$ four days after the injection of streptozotocin were used. Control rats were littermates of the diabetic rats.

Antiserum was raised in white lop-eared rabbits by three subcutaneous injections of equal volumes of $80 \mu \mathrm{g}$ of purified rat hepatic microsomal glucose-6-phosphatase and Freund's complete adjuvant by the method of Burchell [12]. Pre-immune serum was obtained from the rabbits prior to injection with antigen. The glucose-6-phosphatase enzyme used for the injections was isolated from the livers of starved Wistar rats (method available from A. Burchell, manuscript in preparation) and had a specific activity of $32.5 \mu \mathrm{mol} \cdot \mathrm{mg}^{-1} \cdot \mathrm{min}^{-1}$ protein. The purity of the preparation was confirmed by polyacrylamide slab gel electrophoresis in the presence of $0.1 \%$ sodium dodecyl sulphate as described by Laemmli [13]. The final specific activity of the glucose-6-phosphatase enzyme was the highest ever reported. However, it is likely that some inactivation of the enzyme may have occurred during purification, as the final enzyme preparation contained only the glucose-6-phosphatase enzyme and was completely free of the 21,000 dalton glucose-6-phosphatase stabilizing protein [14]. Immunochemical analyses were performed by the Ouchterlony double-diffusion technique in $1 \%$ agar [15].

\section{Enzyme assays}

Glucose-6-phosphatase and mannose-6-phosphatase activity were assayed at $30^{\circ} \mathrm{C}$ in a $0.1 \mathrm{ml}$ reaction mixture by the method of Bickerstaff and Burchell [16]. One unit of activity represents $1.0 \mu \mathrm{mol}$ of inorganic phosphate released/min. Non-specific hydrolysis of glucose6-phosphate was assayed as described previously [17]. It averaged less than $3 \%$ of the total glucose-6-phosphatase activity in microsomal fractions. Phosphatidylcholine liposomes were prepared by the method of Cater et al. [18] and added to enzyme assays at a final concentration of $0.1 \mathrm{mg} / \mathrm{ml}$. Protein concentrations were determined by the method of Peterson [19] with bovine serum albumin as standard.

In this paper, microsomes isolated from liver homogenates and assayed without further treatment are referred to as untreated microsomes. To prepare fully disrupted microsomes, untreated microsomes at a protein concentration of $20 \mathrm{mg} / \mathrm{ml}$ in $0.25 \mathrm{~mol}$ sucrose, $5 \mathrm{mmol}$ Hepes $\mathrm{pH} 7.4$ were exposed to $0.5 \%$ lubrol $12 \mathrm{~A}-9$ at $0{ }^{\circ} \mathrm{C}$ for $10 \mathrm{~min}$. The detergent disrupted microsomes were then diluted in assay buffer. The final concentration of lubrol in the assays was always less than $0.005 \%$ and was not inhibitory.

Latency of glucose-6-phosphatase activity is the percentage of the enzyme activity of fully disrupted microsomes that is not expressed in untreated microsomes. Latency was calculated as $100 \times$ (activity in disrupted microsomes - activity in untreated microsomes)/activity in disrupted microsomes [20]. As previously reported [4, 5, 20, 21], untreated microsomes are heterogeneous preparations composed of (a) intact vesicles (intact microsomes) in which the limiting membrane acts as a selective permeability barrier and (b) disrupted structures in which selective permeability is lacking and the enzyme has free access to ionic substrates and inhibitors. The proportion of the two forms is easily quantified by assays of the low $K_{m}$ mannose-6-phosphatase activity that is expressed only in disrupted structures [4]. The activity of intact microsomes was calculated using the following equation: glucose-6-phosphatase activity in intact microsomes $=$ glucose-6-phosphatase activity in untreated microsomes - (glucose-6-phosphatase activity in fully disrupted microsomes $\times$ mannose- 6 -phosphatase activity in untreated microsomes/mannose-6-phosphatase activity in fully disrupted microsomes) $[5,20,21]$.

\section{Preparation and solubilization of microsomes}

Microsomes were prepared from the fresh livers of control Wistar rats and streptozotocin-induced diabetic rats as previously described [21, 


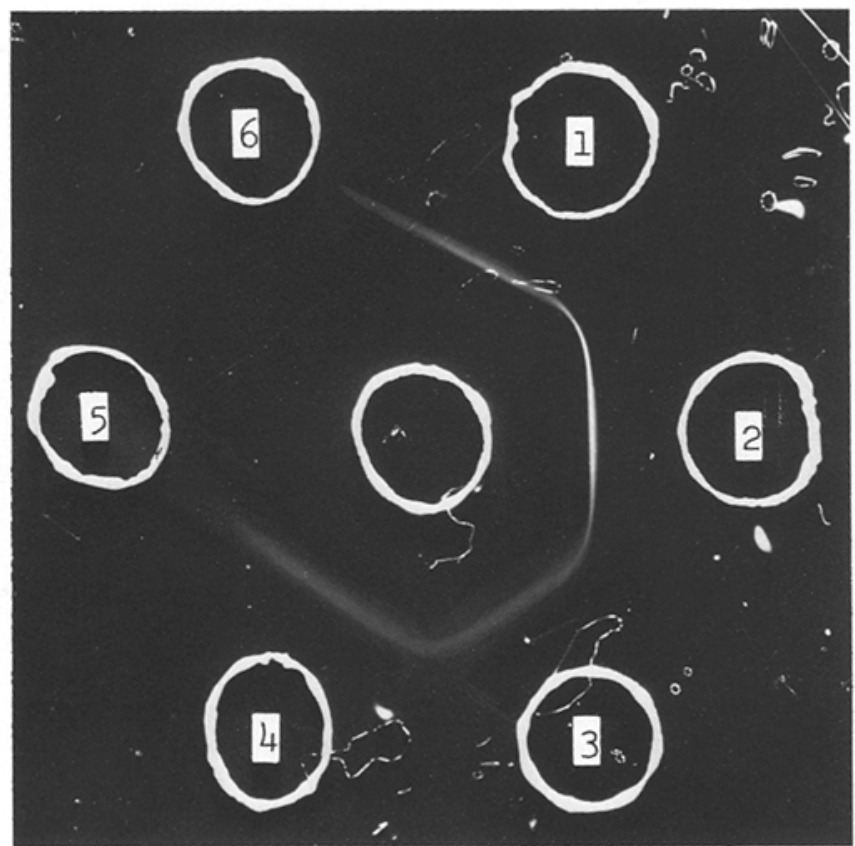

Fig. 3. Ouchterlony double diffusion analysis of fractions from control and diabetic rat liver microsomes. Centre well, rabbit antiserum to purified rat hepatic glucose-6-phosphatase enzyme. (1) Cholate solubilized control rat liver microsomes, (2) Cholate solubilized diabetic rat liver microsomes, (3) fraction 5 from the sucrose gradient centrifugation of diabetic rat liver microsomes, (4) fraction 5 from the sucrose gradient centrifugation of control rat liver microsomes, (5) and (6) $0.25 \mathrm{~mol}$ sucrose, $5 \mathrm{mmol}$ Hepes, $20 \mathrm{mmol}$ sodium fluoride, $1 \%$ sodium cholate $\mathrm{pH} 7.4$ buffer. $20 \mu \mathrm{l}$ of sample was placed in each well

22] and solubilized in the presence of $1 \%$ sodium cholate by the method of Burchell and Burchell [23].

\section{Sucrose density gradient centrifugation}

$4 \mathrm{ml}$ of diabetic or control rat liver microsomes $(20 \mathrm{mg} / \mathrm{ml})$ were carefully layered onto the top of a $12-62 \%(\mathrm{w} / \mathrm{v})$ linear $65 \mathrm{ml}$ sucrose gradient in the presence of $25 \mathrm{mmol}$ Tris acetate $20 \mathrm{mmol}$ Sodium fluoride $0.2 \%$ deoxycholic acid $\mathrm{pH} 7.4$. After centrifugation at $105,000 \mathrm{~g}$ for $18 \mathrm{~h}$ the gradient was fractionated and analysed.

\section{Immunoprecipitation of glucose-6-phosphatase activity}

An equal volume of $90 \%$ saturated ammonium sulphate was added to $10 \mathrm{ml}$ of rabbit antiserum or preimmune serum. After standing for $15 \mathrm{~min}$ in ice, the suspension was centrifuged at $10,000 \mathrm{~g}$ for $10 \mathrm{~min}$. The precipitate was dissolved in $10 \mathrm{ml}$ of $0.25 \mathrm{~mol}$ sucrose $5 \mathrm{mmol}$ Hepes pH 7.4 and dialyzed overnight against the same buffer. The partially purified antibody was then stored at $4^{\circ} \mathrm{C}$ until use.

The partially purified antibody preparations were incubated with cholate solubilized microsomes in the presence of $5 \mathrm{mmol}$ Hepes, $0.25 \mathrm{~mol}$ sucrose, $20 \mathrm{mmol}$ sodium fluoride $0.2 \%$ cholic acid $\mathrm{pH} 7.4$ for $1 \mathrm{~h}$ on ice. The mixtures were then centrifuged at $10,000 \mathrm{~g}$ for $5 \mathrm{~min}$. The supernatants were removed for assay. The immunoprecipitates were washed by resuspension in $0.5 \mathrm{ml}$ of 0.25 sucrose, $20 \mathrm{mmol}$ sodium fluoride, $5 \mathrm{mmol}$ Hepes $\mathrm{pH} 7.4$ and the pellets were recovered by further centrifugation at $10,000 \mathrm{~g}$ for $5 \mathrm{~min}$. The washed immunoprecipitates were resuspended in $0.25 \mathrm{~mol}$ sucrose $20 \mathrm{mmol}$ sodium fluoride, $5 \mathrm{mmol}$ Hepes pH 7.4 and assayed immediately.
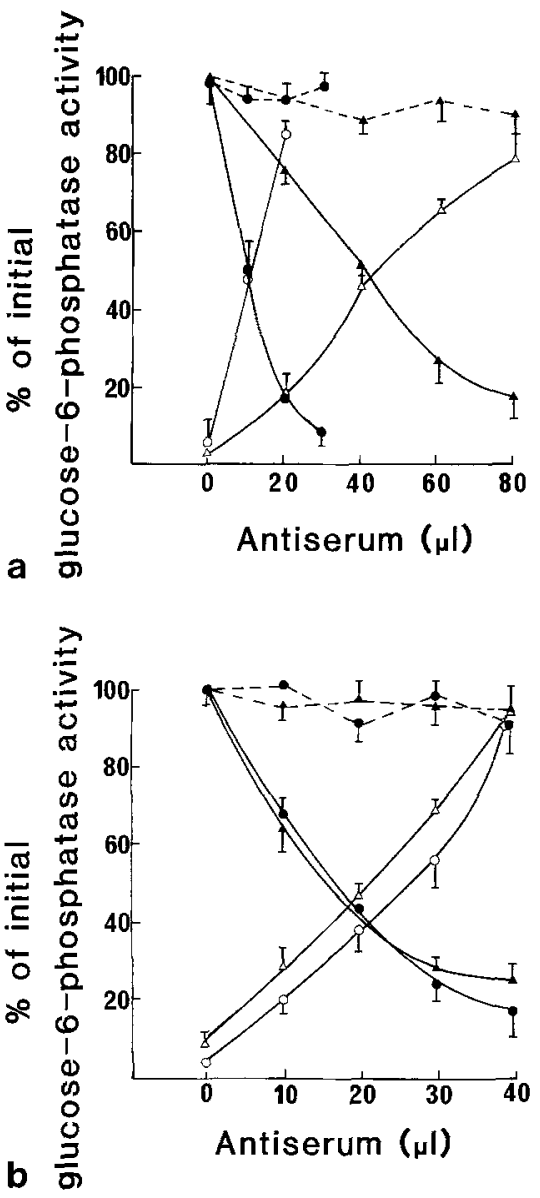

Fig. $4 \mathrm{a}$ and b. Immunoprecipitation of glucose-6-phosphatase activity from solubilized control and diabetic rat liver microsomes. Antiserum raised against rat hepatic microsomal glucose-6-phosphatase was used to precipitate glucose-6-phosphatase activity from cholate solubilized control and diabetic rat liver microsomes. $\triangle \longrightarrow \triangle$ diabetic glucose-6-phosphatase activity in immunoprecipitate; $\mathrm{O}-\mathrm{O}$ control glucose-6-phosphatase activity in immunoprecipitate; $\Delta-\mathbf{\Delta}$ diabetic glucose-6-phosphatase activity remaining in supernatant; control glucose-6-phosphatase activity remaining in supernatant; ---- denotes values obtained using control serum. a The experiment was carried out with a fixed amount of microsomal protein $(0.15 \mathrm{mg})$ in the incubation mixture. One hundred \% activity was $0.13 \mu \mathrm{mol} \cdot \mathrm{ml}^{-1} \cdot \mathrm{min}^{-1}$ in incubations of diabetic material and $0.033 \mu \mathrm{mol} \cdot \mathrm{ml}^{-1} \cdot \mathrm{min}^{-1}$ in incubations of control material. Data are the average from at least 3 different experiments. The bars show the range of values that were obtained. $\mathbf{b}$ The experiment was carried out with a fixed amount of glucose-6-phosphatase activity $(0.066 \mu \mathrm{mol} \cdot-$ $\left.\mathrm{ml}^{-1} \cdot \mathrm{min}^{-1}\right)$ in the incubation mixture. Data are the average from at least 3 different experiments. The bars show the range of values that were obtained

\section{Results}

Comparison of hepatic microsomal glucose-6-phosphatase activity in control and diabetic rats

Glucose-6-phosphatase activity was measured in disrupted and intact microsomes from fed and diabetic rats. The specific activity of the glucose-6-phosphatase enzyme was increased approximately 4 -fold in the diabetic animals and the latency of the enzyme was also greatly increased (Table 1). 


\section{Comparison of the solubilized glucose-6-phosphatase enzyme from control and diabetic Wistar rat liver}

The solubilized glucose-6-phosphatase enzymes from control and diabetic rat livers were equally labile when incubated at $30^{\circ} \mathrm{C}$ (Fig. 1). Glucose-6-phosphatase activities from control and diabetic rats could both be stabilized in the presence of sodium fluoride (Fig.1). During density gradient centrifugation the control and diabetic rat liver glucose-6-phosphatase enzyme migrated to the same position (Fig. 2). The control and diabetic rat liver microsomal glucose-6-phosphatase were immunologically identical as judged by Ouchterlony double diffusion analysis (Fig. 3). These results all indicate that the solubilized glucose-6-phosphatase enzymes from diabetic and control rats are very similar.

\section{Immunoprecipitation of the \\ hepatic microsomal glucose-6-phosphatase enzyme from control and diabetic rats}

Antiserum raised against purified glucose-6-phosphatase enzyme from starved Wistar rat livers was used to precipitate the glucose-6-phosphatase activity from solubilized microsomes of normal and diabetic animals. The antiserum was not inhibitory and did not alter the catalytic activity of the glucose-6-phosphatase enzyme.

Equal amounts $(0.15 \mathrm{mg}$ of protein) of solubilized microsomes from the livers of fed and diabetic rats were incubated with antibody as described in the Methods section; under these conditions approximately four times as much antibody was required to precipitate the glucose-6-phosphatase activity from diabetic microsomes than from microsomes of control animals (Fig. 4a). Not surprisingly, when equal amounts of glucose-6-phosphatase activity were added to the incubation, the same amount of antibody precipitated the same amount of activity from the microsomes of both fed and diabetic animals (Fig. 4b).

\section{Discussion}

Glucose-6-phosphatase activity was first shown to be increased in the diabetic state in 1954 [1]. The increased activity of glucose-6-phosphatase in diabetes could be due either to increased glucose-6-phosphatase enzyme activity or to increased transport capacity of $T_{1}, T_{2}$ or $T_{3}$. Garland et al. [24] showed that glucose-6-phosphatase activity was still increased after diabetic rat liver microsomes were treated with detergent. Arion et al. [5] demonstrated that in streptozotocin-induced diabetes in the rat, glucose-6-phosphatase enzyme activity was increased 3-4 fold without appreciably altering the activity of the translocases. We confirmed these results by showing that a) the activity of glucose-6-phosphatase enzyme was 4-fold higher in disrupted microsomes from diabetic rats than in those from control rats, and b) the latency of the glucose-6-phosphatase system in the intact microsomes was much higher in diabetic rats than in control rats (Table 1).

Glucose-6-phosphatase activity levels have also been shown to change after dietary experiments and following treatment of animals with drugs or hormones $[1,2,11,25,26]$. A number of studies have been undertaken to determine whether the different levels of glucose-6-phosphatase are due to covalent modification of the enzyme or to changes in the levels of the enzyme protein $[1,25,27-29]$. The experimental protocol for most of these studies was either to pretreat animals with actinomycin D and/or cycloheximide or to administer actinomycin $\mathrm{D}$ and/or cycloheximide at the same time as the drug or hormone. The results obtained in these experiments were somewhat variable and contradictory because no direct measurements of glucose-6-phosphatase protein levels were made.

One possible mechanism by which the activity of the glucose-6-phosphatase enzyme might be increased in diabetes is covalent modification of the existing enzyme protein. In this case, some of the properties of the modified enzyme might be altered. Arion et al. [5] determined that the $\mathrm{Km}$ of the control and diabetic enzyme in disrupted microsomes was identical. We found that solubilized glucose-6-phosphatase enzyme from control and diabetic rats was both (a) equally labile at $30^{\circ} \mathrm{C}$ (Fig. 1); (b) stabilized completely by sodium fluoride (Fig.1) as described previously [17] for solubilized glucose6-phosphatase from rabbits; (c) migrated to identical positions during sucrose density gradient centrifugation (Fig. 2) and (d) were immunologically identical as judged by Ouchterlony double diffusion analysis (Fig. 3). These results demonstrate that the difference in activity exhibited by the glucose-6-phosphatase enzyme from control and diabetic rats is very unlikely to be due to covalent modification.

A second plausible mechanism increasing glucose6-phosphatase activity in diabetes could involve the accumulation of enzyme protein. To establish if this was a likely mechanism we have immunoprecipitated the glucost-6-phosphatase enzyme from control and diabetic rats (Figs. $4 \mathrm{a}$ and $4 \mathrm{~b}$ ). These experiments show that the increased levels of glucose-6-phosphatase activity in streptozotocin-induced diabetes are due to increased levels of glucose-6-phosphatase enzyme protein.

In conclusion, we have determined that the increased hepatic microsomal in glucose-6-phosphatase activity in streptozotocin-induced diabetic rats is due to the presence of increased levels of the glucose-6-phosphatase enzyme protein.

Acknowledgements. We thank Dr. B. Burchell and Mr. M. R. Jackson for their advice and encouragement, and the British Diabetic Association for financial support. A. B. is a Royal Society 1983 University Research Fellow. 


\section{References}

1. Ashmore J, Weber G (1959) The role of hepatic glucose-6-phosphatase in the regulation of carbohydrate metabolism. In: Harris RS, Marrian GF, Thannan KU (eds) Vitamins and hormones, Vol 17. Academic Press, New York, pp 41-132

2. Nordlie RC (1981) Multifunctional glucose-6-phosphatase characteristics and functions. In: Veneziale CM (ed) Regulation of carbohydrate formation and utilization in mammals. University Park Press, New York, pp 291-314

3. Arion WJ, Wallin BK, Lange AJ, Ballas LM (1975) On the involvement of a glucose-6-phosphatase transport system in the function of microsomal glucose-6-phosphatase. Mol Cell Biochem 6: 75-83

4. Arion WJ, Ballas LM, Lange AF, Wallin BK (1976) Microsomal membrane permeability and the hepatic glucose-6-phosphatase system. J Biol Chem 251: 4901-4907

5. Arion WI, Lange AJ, Walls HE, Ballas LM (1980) Evidence of the participation of independent translocation for phosphate and glucose-6-phosphate in the microsomal glucose-6-phosphatase system. J Biol Chem 255: 10396-10406

6. Lange AJ, Arion WJ, Beaudet AL (1980) Type $1 \mathrm{~B}$ glycogen storage disease is caused by a defect in the glucose-6-phosphate translocase of the microsomal glucose-6-phosphatase system. J Biol Chem 255: 8381-8384

7. Schaub J, Heyne K (1983) Glycogen storage disease Type 1 B. Eur J Pediatr 140: 283-288

8. Nordlie RC, Sukalski K, Munoz JM, Baldwin JJ (1983) Type 1 C, a novel glycogenesis. J Biol Chem 258: 9739-9744

9. Arion WJ, Lange AJ, Ballas LM (1976) Quantitative aspects of relationship between glucose-6-phosphate transport and hydrolysis for liver microsomal glucose-6-phosphatase system. J Biol Chem 251: 6784-6790

10. Nordlie RC, Arion WJ (1965) Liver microsomal glucose-6-phosphatase, inorganic pyrophosphatase and pyrophosphate glucose phosphortransferase. J Biol Chem 240: 2155-2164

11. Nordlie RC (1971) Glucose-6-phosphatase, hydrolytic and synthetic activities. In: Bayer PD (ed) The enzymes, 2nd edn, Vol 4. Academic Press, New York, pp 33-117

12. Burchell B (1978) Substrate specificity and properties of uridine diphosphate glucuronyltransferase purified to apparent homo geneity from phenobarbital-treated rat liver. Biochem J 173: $749-757$

13. Laemmli UK (1970) Cleavage of structural proteins during the assembly of the head of the bacteriophage T4. Nature 227:680-685

14. Burchell A, Burchell B, Monaco M, Walls HE, Arion WJ (1985) Stabilization of glucose-6-phosphatase activity by a 21,000 dalton hepatic microsomal protein. Biochem J 230: 489-495

15. Ouchterlony O (1958) Diffusion-in-gel methods for immunological analysis. In: Kallow P (ed) Progress in allergy, Vol. V. Karger, Basel, pp 1-78

16. Bickerstaff GF, Burchell B (1980) Studies on the purification of hepatic glucose-6-phosphatase. Biochem Soc Trans 8: 389-390
17. Burchell A, Burchell B (1980) Stabilization of partially purified glucose-6-phosphatase by fluoride. Is enzyme inactivation caused by dephosphorylation? FEBS Lett 113: 180-184

18. Cater BR, Trivedi P, Hallinan T (1975) Inhibition of glucose6-phosphatase by pure and impure c-type phospholipases. Biochem J 148: 279-294

19. Peterson GL (1977) A simplification of the protein assay method of Lowry et al. Which is generally more applicable? Anal Biochem $83: 346-356$

20. Arion WJ, Walls HE (1982) The importance of membrane integrity in kinetic characterizations of the microsomal glucose-6-phosphatase system. J Biol Chem 257: 11217-11220

21. Arion WJ, Lange AJ, Walls HE (1980) Microsomal membrane integrity and the interactions of phlorizn with the glucose-6-phosphatase system. J Biol Chem 255: 10387-10395

22. Arion WJ, Burchell B, Burchell A (1984) Specific inactivation of the phosphohydrolase component of the hepatic microsomal glucose-6-phosphatase system by diethyl pyrocarbonate. Biochem J 220: 835-842

23. Burchell A, Burchell B (1982) Identification and purification of a liver microsomal glucose-6-phosphatase. Biochem J 205: 567-573

24. Garland RC, Cori CF, Chang HW (1974) Relipidation of phospholipid-depleted microsomal particles with high glucose-6-phosphatase activity. Proc Natl Acad Sci USA 71: 3805-3809

25. Nordlie RC (1974) Metabolic regulation by multifunctional glucose-6-phosphatase. In: Horecker BL, Stadtman ER (eds) Current topics in cellular regulation, Vol 8. Academic Press, New York, pp 33-117

26. Nordlie RC, Sukalski KA (1985) Multifunctional glucose-6-phosphatase: a critical review. In: Martonosi, A (ed) The enzymes of biological membranes, Vol 2. Plenum Press, New York London, pp 349-398

27. Freedland RA, Harper AE (1958) Metabolic adaptions in higher animals, J Biol Chem 233: 1041-1044

28. Sato M, Suketo Y (1980) Changes in glucose-6-phosphatase activity in liver and kidney of rats treated with a single large dose of fluoride. Toxicol App Pharmacol 52:386-390

29. Arion WJ, Nordlie RC (1967) Biological regulation of inorganic pyrophosphate-glucose phosphotransferase and glucose-6-phosphatase. J Biol Chem 242: 2207-2210

Received: 25 March 1985

and in revised form: 9 July 1985

Dr. A. Burchell

Department of Biochemistry

Medical Sciences Institute

University of Dundee

Dundee DD1 4HN

Scotland 